\title{
The Coletivo: A feminist sexuality and health collective in Brazil
}

Margarita Diaz

Debbie Rogow

Jose Barzelatto

Follow this and additional works at: https://knowledgecommons.popcouncil.org/departments_sbsr-pgy

Part of the Family, Life Course, and Society Commons, International Public Health Commons, Public Health Education and Promotion Commons, and the Women's Health Commons How does access to this work benefit you? Let us know!

\section{Recommended Citation}

Diaz, Margarita, Debbie Rogow, and Jose Barzelatto. 1995. "The Coletivo: A feminist sexuality and health collective in Brazil," Quality/Calidad/Qualité no. 6. New York: Population Council. 
Quality/Calidad/Qualité, a publication of the Population Council, highlights examples of family planning and reproductive health programs that are providing unusually high quality care. This series is part of the Council's Robert H. Ebert Program on Critical Issues in Reproductive Health and Population which, through scientific and practical efforts, seeks to improve and expand the scope and quality of reproductive health care. The philosophical foundation of the program, and of this series, is that women and their partners have a fundamental right to respectful treatment, information, choice and follow-up from reproductive health care providers. The pamphlets reflect one of the four main thrusts of the program: enhancing the quality of family planning programs.

Projects are selected for documentation in the Quality/Calidad/Qualité series by an Advisory Committee made up of individuals who have a broad range of experience within the field of reproductive health and are committed to improving the quality of services. These projects are making important strides in one or more of the following ways: broadening the choice of contraceptive methods and technologies available; providing the information clients need to make informed choices and better manage their own health care; strengthening the quality of client/provider interaction and encouraging continued contact between providers and clients; making innovative efforts to increase the management capacity and broaden the skills of service providers at all levels; expanding the constellation of services and information provided beyond those conventionally defined as "family planning;" and reaching underserved and disadvantaged groups with reproductive health care services.

None of the projects documented in the series is being offered as a model for replication. Rather, each is presented as an unusually creative example of values, objectives and implementation. These are "learning experiences" that demonstrate the self-critical attitude required to anticipate clients' needs and find affordable means to meet them. This reflective posture is exemplified by a willingness to respond to changes in clients' needs as well as to the broader social and economic transformations affecting societies. Documenting the critical choices these programs have made should help to reinforce, in practical terms, the belief that an individual's satisfaction with reproductive health care services is strongly related to the achievement of broader health and population goals.

\section{ONDIILATION COTRCTL TTBRATY

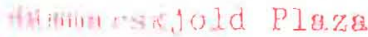

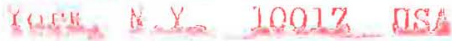

Publication of this edition of Quality/Calidad/Qualité is made possible by support provided by the Ford Foundation, the John D. and Catherine T. MacArthur Foundation and the Swedish International Development Authority (SIDA).
Statements made and views expressed in this publication are solely the responsibility of the authors and not of any organization providing support for Quality/ Calidad/Qualité. 


\title{
The Coletivo: A Feminist Sexuality and Health Collective in Brazil
}

\author{
by Margarita Diaz and Debbie Rogow \\ Introduction by José Barzelatto
}

\section{Introduction}

In the past, family planning programs were designed primarily to reduce excessive population growth, making women the objects of medicalized policies and programs designed to regulate fertility. The result was vertical programmatic approaches that hindered the development of comprehensive services. This approach was driven by a "disease perspective," which was the natural outcome of the successful track record of medicine for finding "technological fixes" oriented at solving biological problems. It is this biomedical approach to fertility, combined with cultural myths and taboos, that has prevented population programs from adequately addressing sexuality and gender issues. Amazingly, even though sexuality is at the core of reproductive life, until AIDS, family plamning programs operated quite successfully without even mentioning the word "sex."

But, as the Plan of Action adopted at the 1994 World Population Conference in Cairo attests, the population field has begun to shift its focus from the "population explosion" to the sexual and reproductive health of individual citizens. There are a number of important factors behind this shift. One factor is the recent global trend towards the strengthening of civic society. There has been an upsurge of democracy movements and increased participation of non-governmental players in the development of national and international policies. A second factor has been the growing recognition that sexual and reproductive health is an important social good, worth pursuing regardless of demographic circumstances.

The most important factor, however, has been the changing needs of and opportunities for women. In the past, high mortality and women's inability to regulate their fertility contributed to clearly defined gender roles: women reproduced and men produced. The fact that we have patriarchal societies is no accident. But lower mortality rates and increased fertility regulation have led to changes in the balance between reproduction and sexuality in relationships. Now more than ever, childbearing can be initiated according to the desires and decisions of a couple, rather than by accident, and women can become equal partners with men in all aspects of life.

This transition in sexual and gender roles and the responsibilities they entail will have a far greater impact on humankind than will the demographic transition. By concentrating on population growth, the population field has focused on a very important, but transitory phenomena. Demographic transitions have taken from twenty to one hundred years, depending on the existence or not of effective family planning programs, but will probably happen anyway at varying social costs. What is less predictable and more crucial are the changes in the balance of roles and power between women and men. We are beginning to understand the consequences and just how deeply society may be influenced by these changes. 
The women's movement has been primarily responsible for placing all these issues in the public arena. Today women's organizations are working to counteract the overmedicalization of reproductive and sexuality issues; to empower communities, particularly women; to redefine gender roles and responsibilities; and to promote informed public dialogue on these issues. It is because of the crucial role they play that the Ford Foundation now supports a number of women's health movements around the world.

While these issues are of central concern everywhere, the women's health movement in Latin America has taken on the issues of sexuality and human relationships in a way that is probably more dynamic than in other part of the world. It is, therefore, fitting that we look to that region for ideas on how to implement a reproductive and sexual health approach. This is particularly appropriate in terms of a number of issues the family planning field has long been concerned about, such as quality of care and integrated service design as well as provider training and motivation.

The women's movement has shown us that it is possible to translate a sexual and reproductive health approach into services, and that this can be accomplished even with modest resources, as the Women's Sexuality and Health Collective in São Paulo, Brazil has done. Services like those of the Coletivo demonstrate that it is more efficient to have satisfied clients who use family planning methods appropriately than it is to simply distribute contraceptives without caring about what people do with them.

This brings up two crucial issues: provider motivation and the provider-client relationship. It is not surprising that when providers feel overworked and are poorly paid, they do not treat their clients well. Most client dissatisfaction is, in fact, due to the poor quality of their encounter with a provider. The Coletivo shows us the importance of the provider-client relationship and reminds us that we must offer clinic staff a meaningful work experience and a reasonable salary to improve her/his position in life. At the Coletivo, staff feel that they are personally and professionally benefiting from their work and it shows in the quality of services they provide.

In many family planning clinics, the standard unit of evaluation - in fact the only data readily available-is the number of contraceptives distributed or the number of new clients who have been seen. But if you do a real evaluation of a client's needs, and then try to address those needs, there is evidence that good quality services not only offer positive results from a reproductive and sexual health perspective, but from a demographic perspective as well. In the case of the Coletivo, while every woman who comes to the clinic may not leave with contraception (maybe because she does not want to contracept right now or because she has an infection), she does leave with a sense that her overall well-being is of concern to someone. Thus, she is likely to return for other services, perhaps even contraceptive services. Additionally, those women who do leave with a contraceptive method are more likely than their counterparts at conventional family planning clinics to use the method of their choice effectively, or to come back for an alternative method if they feel they need one. This clearly illustrates the necessity to do more than just train providers to distribute a range of contraceptive methods.

What the sexual and reproductive health approach does is place sexuality at the core of reproductive life. It challenges what medicine and family planning have been about and calls for a more-humanistic and holistic approach to health. It is not enough for the doctor or family planning provider to merely diagnose what is wrong with a woman's body or decide what contraceptive would suit her best. Human beings are more than biology, and if you look carefully at their problems, you will not be able to isolate contraception as a separate issue. What is necessary is to listen to what people-in particular women-have to say about their own physical, mental and social needs, and then try to address those needs.

Over the past decade, the women's health movement and the population field have begun to engage in meaningful dialogue. Despite perceived risks of compromise for each side, these conversations are crucial as both work towards a broader agenda of reproductive and sexual 
health. Ironically, this process is not unlike some of the changes occurring in gender relationships around the world. As traditional roles change and mutual respect and understanding are cultivated, a type of marriage is formed where neither partner is necessarily diminished. This is because such a partnership must be a two-way street and neither the assumption of bad motivation nor absolute confrontation is constructive.

These dialogues have already had a broad impact. Women's organizations, such as the Coletivo, have worked with more established institutions, such as the Population Council and the World Health Organization, to enhance the use of existing contraceptive technologies (like the diaphragm), and to develop new technologies that are women-controlled and offer protection against infection. As a result of such dialogues, biomedical contraceptive research is now beginning to be directed also by users' perceived and expressed needs and not only by scientific research opportunities.

We are just beginning to understand the complexity and depth of the changes we think are necessary in the population field and beyond, and we are still looking for ways to achieve them. It is not surprising that calls for such change are meeting resistance since they pose challenges to existing social structures and religious values. This underscores the importance of coming together to exchange ideas and explore strategies; to hear the multiple voices of civic society, including ethical and religious perspectives. It is not enough to provide good services to a few people. We must also be concerned with improving the lives of the majority of people-as the Coletivo has attempted to do-through dialogue, advocacy, research and training.

The members of the Women's Sexuality and Health Collective are pioneering new ways to provide services and involve women in their own health care. Through groups like the Coletivo, the women's movement shows us what is possible. We must be willing to take up the challenge. 


\section{Background}

This issue of Quality/Calidad/Qualité $(Q / C / Q)$ tells the story of a group of Brazilian women who came together in 1981. What brought them together was their belief--not as widely understood then as it is now-that conventional approaches to women's health and family planning services were overly medicalized, incapable of dealing with the relationship between sexuality and contraception and disempowering to clients. This small groupwhose ideas were shaped by their own experiences on the exam table and in the pro-democracy movement-wondered whether an alternative could exist for women in Brazil. They began to imagine what kind of service would foster a broader concern for women's health as well as increase their level of comfort with their bodies and their sense of entitlement and dignity as women in the society. What would such a program look like? What would it stand for? How would it be organized? How could it be affordable for low-income women? How would it measure its success? And what would it take to try to do it?

Out of these bold questions came the birth of the Feminist Sexuality and Health Collective (Coletivo Feminista Sexualidade e Saúde) in São Paulo, Brazil. It is a story that challenges those of us concerned with women's health and well-being to reflect, to ask questions and to imagine.

\section{The First Seeds}

The initial group of five women who met in 1981 began with the idea of learning more about their own bodies, sharing that knowledge and using it as a base for organizing women around choices - choices about health care and contraception, about sex and maternity, about the rights of women. The name they chose for their group reflects the four issues that defined what they shared and what they cared about: Feminism. Sexuality. Health. Collective.

Over the next few years, while the Coletivo was engaged in this educational process, they also contemplated the need for a high quality, comprehensive clinical service that truly responded to women's reproductive health needs. By 1984, it had become clear that no one was providing women with the kind of service delivery they envisioned, so the Coletivo members set themselves an ambitious agenda: they would create their own clinic.

Planning the clinic took two years. By this time the group had evolved to eleven women, all from different backgrounds: about half had a university education (including two physicians) and half were housewives and community activists. Some were from the middle class and others from the ranks of the poor. For most of 1984 and 1985, Coletivo members met weekly to clarify their objectives, design their program and carry out training in preparation for initiating services.

\section{Setting Objectives}

By talking with many women about their health care, the Coletivo founders came to understand that for most women, a visit to the gynecologist felt degrading. Doctors spoke at them but did not listen. For many women the gynecological examination was an experience of violence. But how was the Coletivo to create a humanized and empowering experience? One of the group's first priorities was to remedy the tremendous power differential between reproductive health care providers and their female clients. In Brazil, almost all contraceptive and gynecological services are provided by physicians, most of whom are male. Setting aside conventional beliefs about what could and could not be done, the Coletivo decided to train lay women to provide complete basic examinations, with backup by the female clinicians.

A second step toward humanizing services was to ensure that the interaction between client and provider resulted in women leaving the clinic with greater knowledge about and confidence in themselves. This would mean an emphasis on education that, in turn, would allow women to make more of their own choices. Information about one's body and one's sexuality was understood as the starting point for women to make effective choices regarding their sexual and reproductive health.

A primary concern among collective members was the usual fragmentation of women's bodies and health needs into different service domains. The Coletivo favored an integrated service that recognized a woman's medical needs are directly interrelated with her sexuality, her social role, her economic activities 


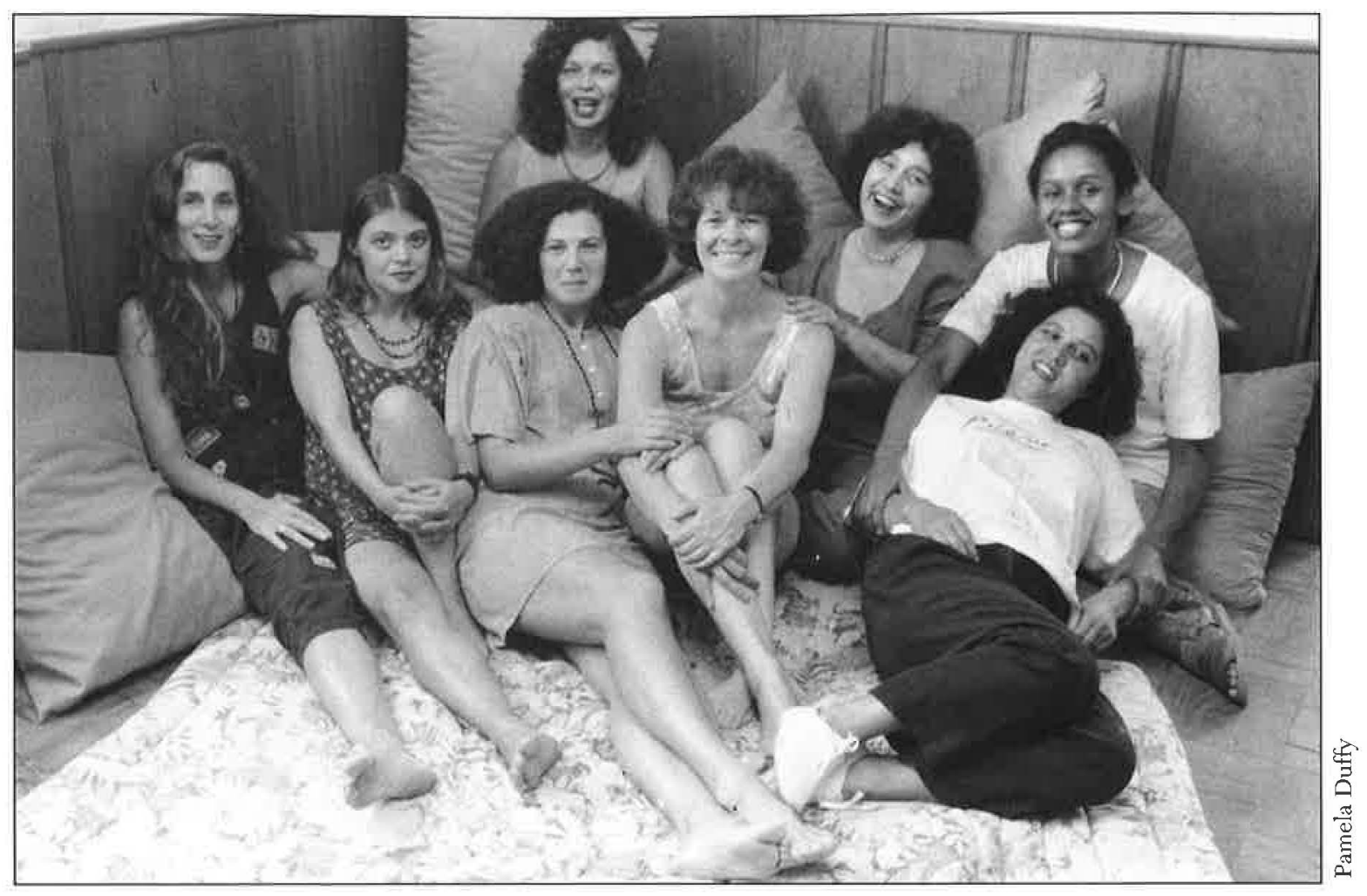

and her emotional well-being. This would mean providing nutrition education, psychological counseling and education about reproductive rights. An integrated approach also meant that the client would see the same person for both her initial interview and her clinical exam.

Finally, Coletivo members felt that health care had become too oriented toward curative medicine, and that overreliance on drugs was often masquerading as technical competence. Instead they chose an approach that emphasized prevention and the use of natural remedies to reduce overdependence on technology and drugs.

Turning these broad goals into a concrete program design required input from many sources. Collective members spoke to women from all walks of life about what kind of health care they wanted and considered the experiences of the feminist health movement in other places. Under the sponsorship of ISIS (an international women's organization), physician member Maria José de Araujo completed a nine-month rotation at the Dispensaire des Femmes, a feminist health clinic in Geneva. Maria José explains that this visit was of fundamental importance for the Coletivo. "We had imagined such a service, but we had never seen it. Yet there I saw the very principles we had discussed put into practice. The Dispensaire had learned which plants and herbs it could reliably recommend. The staff members had created a new kind of patient-doctor relationship. They believed in the power of knowledge. We knew a clinic in Brazil would have to be different from one in Switzerland, but this exposure was very formative for us."

Upon Maria Josés return, convinced their bold scheme was indeed a possibility, the Coletivo set about refining its program plan, developing a financial base and conducting a training program.

\section{Getting Started}

One of the most formidable tasks was training nonclinician members to perform pelvic exams and basic lab tests. This process was managed by Maria José along with two other members, Melodie Venturi and Simone Diniz. Melodie is originally from the United States, where she was trained as a physician's assistant. (A relatively new profession, the physician's assistant is trained as a primary care 
clinician who works with medical backup.) Melodie also had previous experience working with a feminist health center in her country. Simone is a physician. Joining Maria José, Simone and Melodie was Rosangela Gramone, a biologist sent by the Dispensaire in Geneva to help them get started.

Every day for five months, Collective members attended half-day sessions on basic anatomy and physiology, sexuality, reproductive diseases, contraception, preventive care and a clinical practicum.

A small house in a working class neighborhood of São Paulo was rented. A modest grant from Rina Niccim of the Dispensaire in Switzerland supported the purchase of exam tables and basic clinical equipment. The secondhand furniture, lights and refrigerator were all donated.

The clinic's first clients were the Coletivo members themselves. Then came their friends and finally, in 1986, the clinic was opened to the public.

Today Coletivo members look back at their original staffing plans with a smile. In an attempt to challenge the typical hierarchical power relationships among staff membersparticularly health providers-the group de- cided that everyone would learn to do all the jobs at the clinic and that they would simply rotate their functions.

It didn't take long before Coletivo members had to acknowledge that people have different skills and different interests. One member reminisces, "A lot of our early experiences were based on fantasy. We believed everyone had more or less the same abilities and interests. So we thought everyone should do exams and everyone should do cleanup. But we saw that some of the women were never going to be competent in the lab. And others made a mess cleaning up! Sometimes it got funny, sometimes it was upsetting. We spent a lot of time being worried over something being poorly done before we gave up on our early notions." Before long, a specific individual assumed responsibility for financial management and the Coletivo hired a secretary who didn't want to perform pelvic exams.

\section{The Coletivo's Program Today}

The Coletivo's activities are roughly divided into five areas: clinical services, educational programs, training, advocacy, and research.

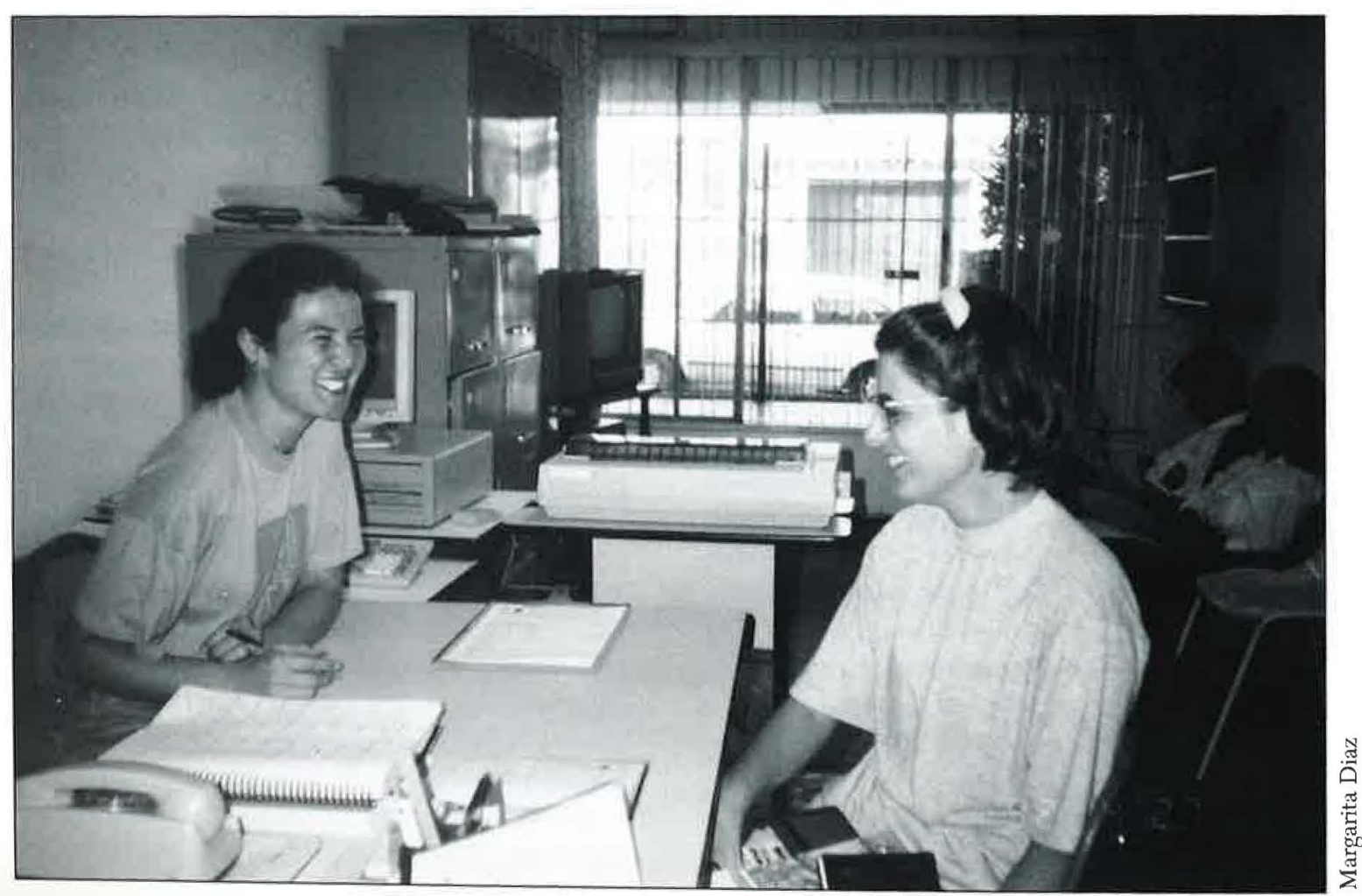


Currently 11 staff members comprise the collective. Most work 20 hours per week because the budget does not allow for this number of full-time positions. Although administrative and management duties are now handled by a designated coordinator, decisions are still made democratically. And most members still perform more than one task. Maria Otacilia Lima Battistelli, for example, participates in research and training activities and also conducts workshops on body awareness.

The annual budget of the Coletivo is about U.S. \$140,000 Previously, client fees (which are based on a sliding scale) accounted for 28 percent of this amount. Over the past few years, the worsening economic situation in Brazil has meant that fees have not kept pace with costs, and client fees now contribute only 17 percent of revenue. None of the Coletivo's programs (including its training program) currently pays for itself.

But the Coletivo's goal has always been to create a model of quality care rather than a model of self-sufficiency; the organization expects to remain dependent on outside donors. The Coletivo started with a small grant from the Dispensaire and currently receives support from private foundations in the U.S. and Europe.

Nor have numbers been a priority. Only about 2500 women pass through the Coletivo's doors every year (most for clinical services alone, but several hundred for educational programs and several hundred for both), and there are no plans to expand. The Coletivo measures its success as a provider on its ability not only to offer care that is respectful of women but in some instances, even transforms their lives.

\section{Clinical Services}

The clinical services begin with a woman filling out her own health history. Along with medical information, the form asks whether or not the woman has a regular partner. Other questions ask whether the woman has any concerns about sexuality and/or experiences with violence that she would like to discuss. These questions help staff to gear the counseling session to the individual situation of each client.

The counseling session reviews the woman's charts and her concerns. The staff member may spend a half hour explaining early

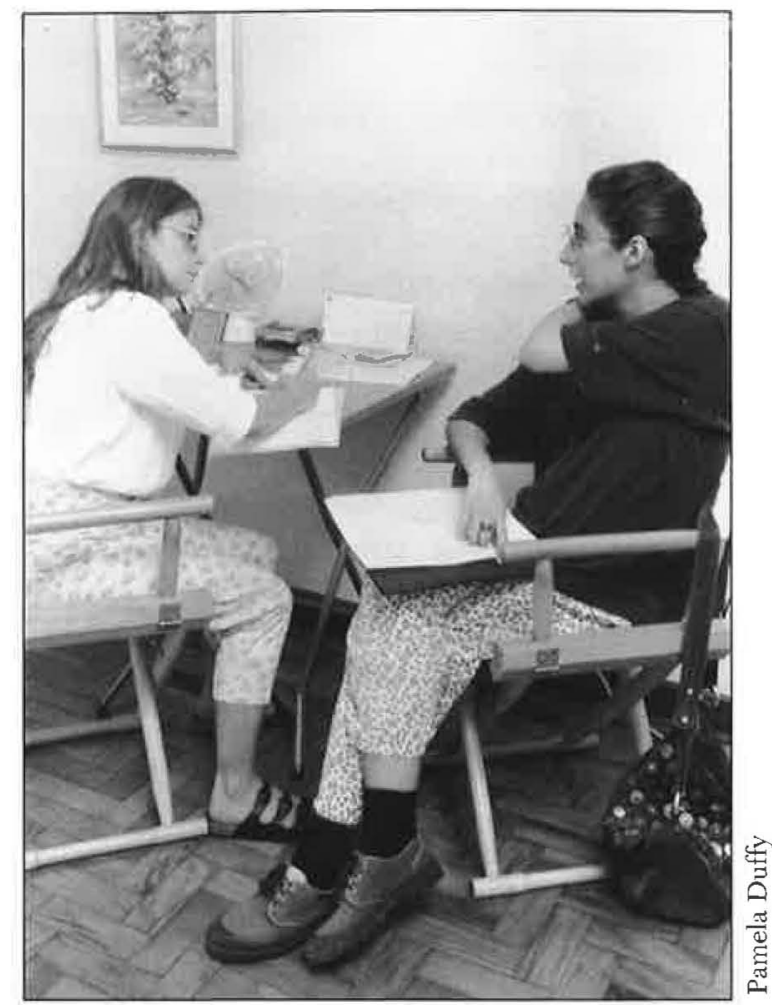

diagnosis, self-treatment and prevention of yeast infections; allowing a woman to talk about experiences of violence; or discussing job stress, fatigue and nutrition.

The clinical exam is then performed by the same person who does the counseling, to break down the barrier between the social and clinical aspects of care and to build more meaningful rapport with the client. The annual gynecological exam includes a bimanual and abdominal exam, a Pap smear, breast exam and review of the breast self-examination technique. The physicians are always available for consultation in difficult cases.

There are aspects to the exam that may shock traditional family planning providers. First, the woman puts in her own speculum. Second, she is offered a chance to see her own cervix with a mirror. Coletivo members find that women tend to be mystified by their own bodies and have no mental picture of their cervix. They have learned that the simple act of showing them a part of their bodies that has been known to their gynecologists and male partners-but not to them-helps women claim their bodies as their own. Another nontraditional aspect of the exam is that the client is welcome to bring her partner into the exam room; 
indeed, a good number of partners do attend. The exam also includes a blood pressure check and screening for reproductive and urinary tract infections. Wet smears and pregnancy tests are performed on site, but gonorrhea and Pap tests are sent to a local lab. Referrals are made for syphilis and HIV testing.

Contraception, pregnancy testing and prenatal care are all available. Contraceptives provided include condoms, spermicides, the diaphragm, natural family planning, pills and the IUD. This range of contraceptive options is remarkable for any clinic in Brazil, where pills and sterilization account for close to 85 percent of all contraceptive use and other methods are almost unavailable. Few providers in Brazil know how to insert IUDs, and far fewer still know how to measure for a diaphragm. Coletivo staff members are fully trained in the clinical and counseling aspects of these methods (the IUD is the only method provided exclusively by the physicians) and are committed to allowing the necessary time to ensure that a client can use her method effectively. For example, in screening for contraindications, the Coletivo staff asks every prospective IUD client not only whether she has more than one sexual partner, but also whether her partner may sometimes have other partners.

Providing this broad but unusual range of choices has not been easy from a management standpoint. Contraceptive provision is not taught in Brazilian medical schools, and there are almost no contraceptive technology training programs available locally. To learn how to insert IUDs, Coletivo physicians had to leave São Paulo (a city of 17 million) for training at CEMICAMP in nearby Campinas, a specialized family planning clinic associated with an international research center. They learned about natural methods from the Swiss Dispensaire.

Providing diaphragms presented even more hurdles. Maria José and Rosangela were able to teach other staff members how to fit diaphragms and teach women how to use them, but procuring supplies of diaphragms and spermicidal jelly and cream proved far more difficult. United States Agency for International Development (USAID)-funded suppliers were not shipping any diaphragms to Brazil, and there was no local manufacturer. Over the years, the Coletivo kept up with the demand by relying on the generosity of institutions such as The Pathfinder Fund and CPAIMC, a large family planning clinic in Rio de Janeiro. Today the Coletivo purchases its diaphragms from Semina, a woman owned and operated manufacturer in Brazil that is itself an outgrowth of the women's health movement.

The Coletivo was strongly motivated to make the diaphragm available. First, members were concerned about the serious lack of contraceptive choice in Brazil, where oral contraceptives remain the only widely accessible temporary method (outside of illegal abortion). They harbored serious concerns about the huge numbers of women for whom the pill was not an appropriate method, either for health or 
personal reasons. Second, because of their concern for women's autonomy, they were interested in a method that women could stop or start (use or not use) independently and that also provides some protection (when used with a spermicide) against infections. And finally, although many programs are unwilling to provide the kind of education and counseling required for effective diaphragm use, for the Coletivo meaningful client-provider interactions are a sine qua non.

At the Coletivo, diaphragm education begins with an introduction to the method. The staff can also teach women fertility awareness techniques so that they do not have to use the diaphragm all month long or can use double protection at the time of ovulation. Concems about how the diaphragm may interfere with sex are discussed openly, and staff members sometimes suggest that their male partner can actually insert the diaphragm as part of lovemaking.

During the exam, women who decide to try the diaphragm are shown their cervix with a mirror and encouraged to touch it with their finger. Maria José explains, "You might think women would be too shy to touch their cervix. But when they see it in the mirror they are amazed. They are curious to know their own bodies when it is made safe for them."

The clinician then establishes the correct diaphragm size for the woman and she is given a chance to try inserting it herself. Finally, she is given appointments for follow-up visits in one week and three months, however, she is encouraged to return at any time if she has a problem.

The Coletivo staff feels strongly that with thorough counseling, methods like the diaphragm can have much wider acceptance. Indeed, as other clinics in the São Paulo area have learned about the availability of the diaphragm services at the Coletivo, they have begun referring increasing numbers of women interested in this method to them. As a result, although the Coletivo's clinical program remains small, the demand for the diaphragm has risen steadily: 40 percent of all contraceptive users coming to the clinic now request this method.
The Coletivo also offers prenatal care, which includes not only regular check-ups but also extensive nutrition counseling along with the Coletivo's natural childbirth/prenatal education and support groups. Male partners usually participate in these groups. They appreciate the considerable attention given to topics such as fathering and the male-female relationship. Arrangements for birthing care are generally made with a nearby hospital or midwife.

In addition to the counseling, which is seen as part of basic medical services, the Coletivo provides more in-depth psychological counseling as needed. Psychologist Otacilia Battistelli sees some clients for up to a year with fees based on a sliding scale.

\section{Shaping the Client-Provider Relationship}

As part of the attempt at demedicalizing health care, there is no formal sign on the front of the Coletivo building. Nor do clients encounter anyone dressed in a white coat. Although the building is clean, there is no strong odor of disinfectant typical of most hospital-based clinics in Brazil. When the client enters, she is greeted by Ceci, the receptionist. If she is new, she is asked to fill out her own medical history form. (Those who cannot read or write are, of course, given assistance.) Having clients complete their own medical records is not just a time-saving device. The staff explains that "a woman's active participation in her own health care begins at this point." Critical information is also entered into a computer database.

An important element of what makes the Coletivo's services unique is time. First visits last about 60 minutes and subsequent visits last about half an hour. According to Maria José, "We have not tried to resolve all health problems women face or to deal with the whole population. We have been trying to show that a high quality of care is possible, but that it requires us to give women more time." While many in the family planning field may find this time allotment unrealistic, the Coletivo staff firmly believe that without providing this amount of time, clients would not be able to 


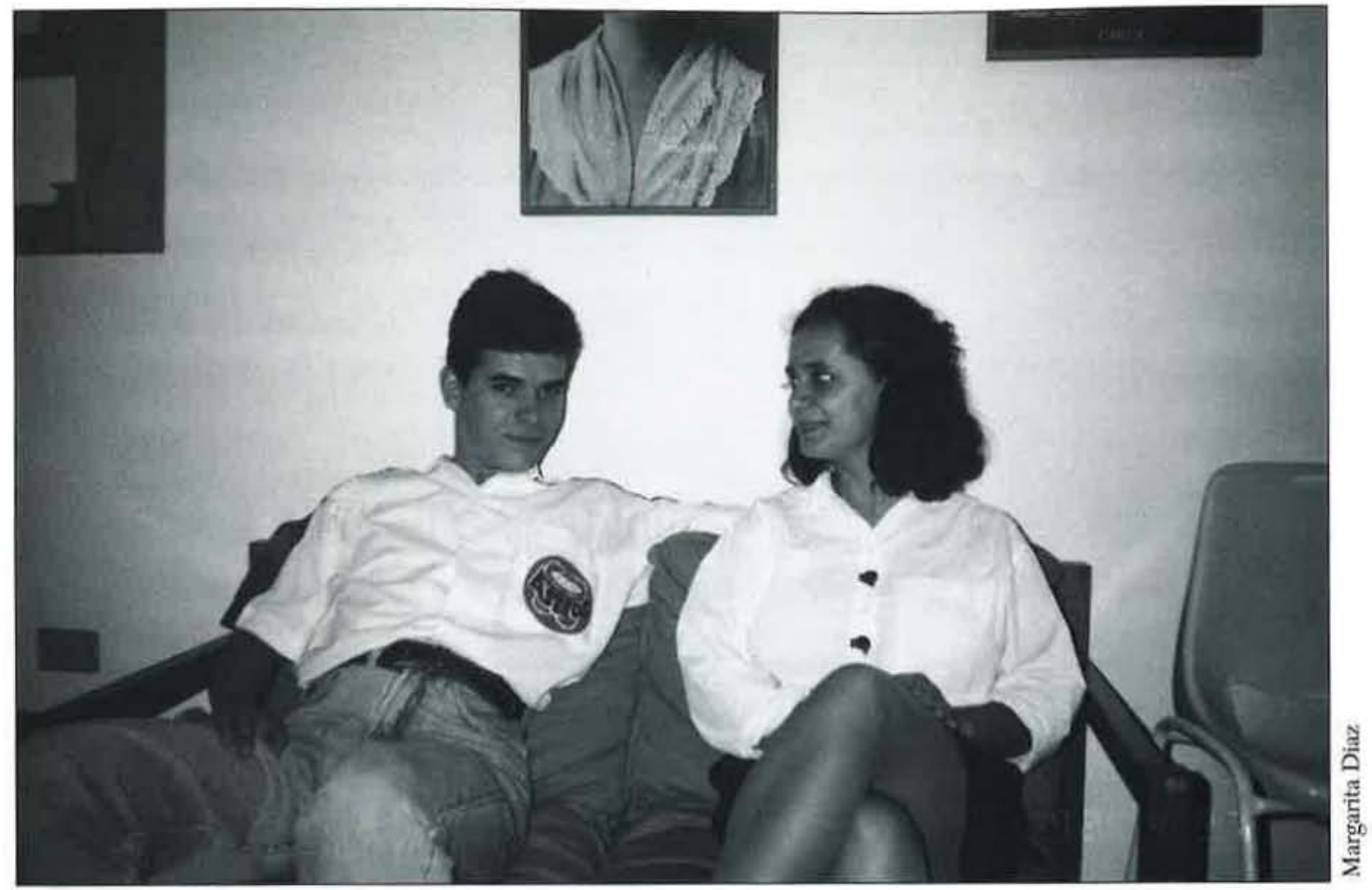

adequately explore their own concerns, learn about their bodies as well as all the services available at the clinic and establish a trusting relationship with their provider.

\section{Voices of Coletivo Clients}

The women who attend the Coletivo are generally from the western part of São Paulo surrounding the clinic. Most (68 percent) clinic clients are poor or working class women. Another 17.8 percent have a middle class income ( 5 to 10 times the minimum salary), and 14.3 percent have an upper-middle-class income (over 10 times the minimum salary). Considering that public sector services are free and that Brazil has been suffering from a severe economic crisis for some time, the large proportion of poor and working class clients who are willing to pay even a small fee for care at the Coletivo is impressive.

Today most Coletivo clients learn about the clinic the same way women did when the Coletivo first opened its doors: through friends. Creuza and Fernando heard about the Coletivo from Fernando's buddy, Jorge. Creuza says, "Jorge told me this place was different, that the doctor spent a lot of time with you, they give you enough attention, and that Fernando could come in with me during the appointment." While waiting for her exam, Creuza reports that she feels happy about being there because she was warmly received and because she liked filling out her own medical history form. Illustrating how much quality care is worth to people, Creuza explains that she traveled for two hours to get to the Coletivo, because good care is worth it.

Twenty-one year-old Roberta is also a new client. A male friend told her that the Coletivo "is a friendly place, where the people make you feel comfortable, and there are no doctors in white coats." Roberta says previously she had been to another provider, where the male doctor made her feel "as if I had been assaulted, humiliated." Here at the Coletivo, she says her visit was "what I hoped for. I found comfort and understanding."

Cristina is a single 30-year-old and has been coming to the Coletivo since it first opened. She explains, "When I was a teenager I went to the gynecologist for help, because I was taking the pill and I didn't feel good. The doctor told me the best method was to get married." Cristina then heard about the Coletivo. 
As she recalls her first visit: "It really moved me, seeing my genital organs in the mirror: The [cervical] self-exam was the thing that affected me the most." Commenting on what else makes the Coletivo different from other providers, Cristina comments, "The visit is a shared responsibility-the doctor-patient relationship is really different from other places." She also mentions the availability of alternative treatments, such as yogurt for certain vaginal infections, as an important advantage.

Crislaine, though only 19 years old, echoes similar sentiments. She describes the birth of her 15-month old as a trauma. She was not allowed to have her husband with her, and her requests for a hand to hold were answered with the doctor's order to "grab the bedpost." Afterward, Crislaine came to the Coletivo for contraception. First and foremost, she values the Coletivo because of its "respect for women's condition."

\section{Education Program}

Because at the Coletivo clinic visits tend to involve a significant amount of client education, the boundary between clinical services and educational components is less distinct than at other institutions. Group workshops are the primary activity of the education component. Simone Diniz, Regina Rodriguez, Melodie and Maria José all lead workshops on such topics as sexuality, self-esteem, adolescence, premenstrual syndrome, nutrition, contraception, menopause and pregnancy/natural childbirth. Most of the workshops meet once a week for eight weeks, but the prenatal group generally continues for five or six months.

All of the workshops rely heavily on interactive techniques that respect the experiences of each participant, underscoring the Coletivo's belief in the power of knowledge. The giving of information and exchange of experiences serve as points of departure for further reflection about one's identity as a woman. The comment of 24-year-old Heliani, as she left her first workshop, is typical: "All this made me think about my body and my role as a woman."
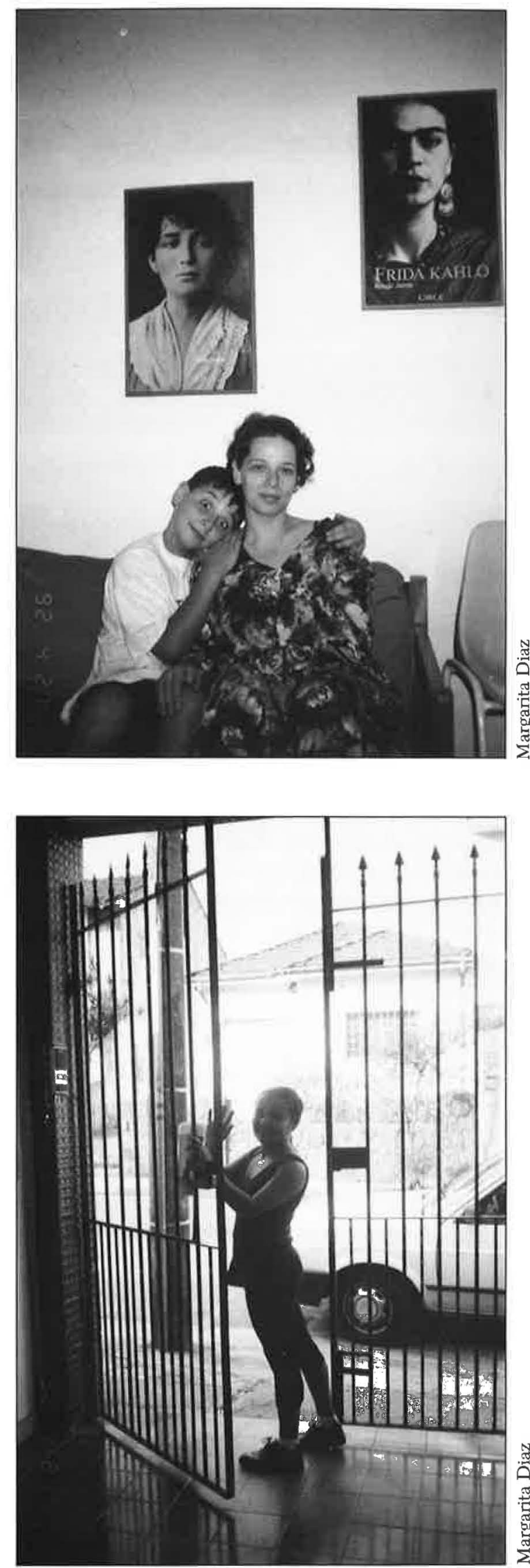


\section{Beyond Service Delivery}

Community development specialist David Korten has argued that the evolution of nongovernmental organizations (NGOs) generally can be defined by the way in which they confront the problem around which they are organized. For example, most NGOs begin by providing immediate relief and welfare services. Then as it becomes evident that the need outstrips the NGO's ability to provide these services, many organizations engage in community organizing and development. Eventually, they move toward addressing the more fundamental causes of the problem through policy change. The most advanced NGOs serve as a national actors and policy voices.

According to this scenario, the Coletivo started out at a fairly sophisticated stage: not only did it intend to meet individual needs through small-scale service provision, but it was also committed to educating women about what is wrong with the current health system and to demonstrating to policymakers what is possible. However, before long it had moved to the third stage as members realized that a model of humanized care, no matter how "successful," would not spontaneously result in other providers following suit. Within three years of its opening, the Coletivo had set up a training institute, developed a research component and begun playing a high-level advocacy role, not only in São Paulo but on a national level as well.

\section{The Training Program}

First came interested visitors from Peru, Colombia, Argentina and other regions of Brazil. Then the Coletivo began sponsoring informal apprenticeships and making presentations at professional conferences. By 1991, the Coletivo had begun a formal training program.

Currently, the Coletivo offers three different courses for health care professionals. The first is a 20-hour seminar on women's health care. Open to both health professionals and interested lay people, this course reviews women's reproductive health care needs from both a technical and a social perspective. Participants learn about topics such as women's limited ability to protect themselves against sexually transmitted disease, reproductive rights as human rights, basic concepts of sexuality and sex education, and skills for fostering an effective group process. The second course is a more in-depth version of the 20-hour course. Although the Coletivo distributes occasional flyers to health professionals, it recruits most attendees by word of mouth. In the past few years, close to 350 participants, mostly female, have enrolled in these courses.

Increasingly, these participants come from all across Brazil. The staff is learning that the course is most useful to participants who have had little or no exposure to these themes from a gender perspective; for them, the course helps shape the way they see clients and enables them to understand how their clients' priorities may differ from those of the health establishment.

Tereza is a nurse who took this course after hearing a friend at work talk about it. She wrote, "After one week of so much information, I wanted to know much more about women's health. I really didn't know there was so much to know. This week changed my life."

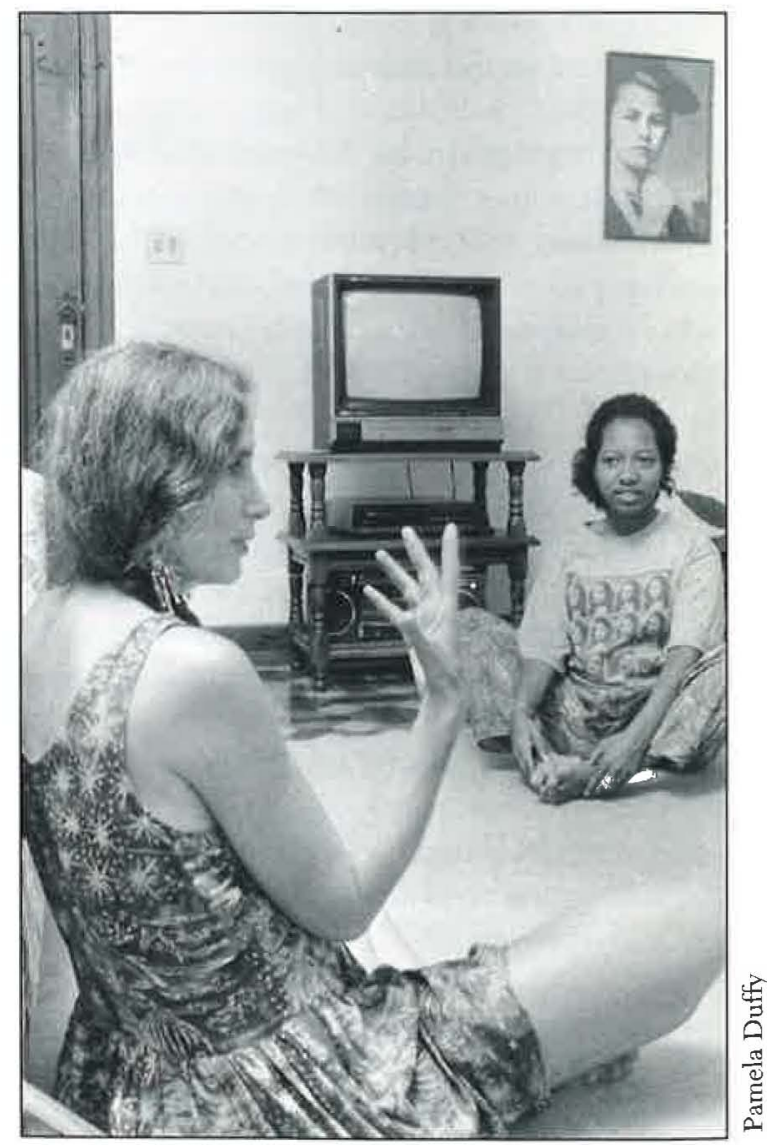




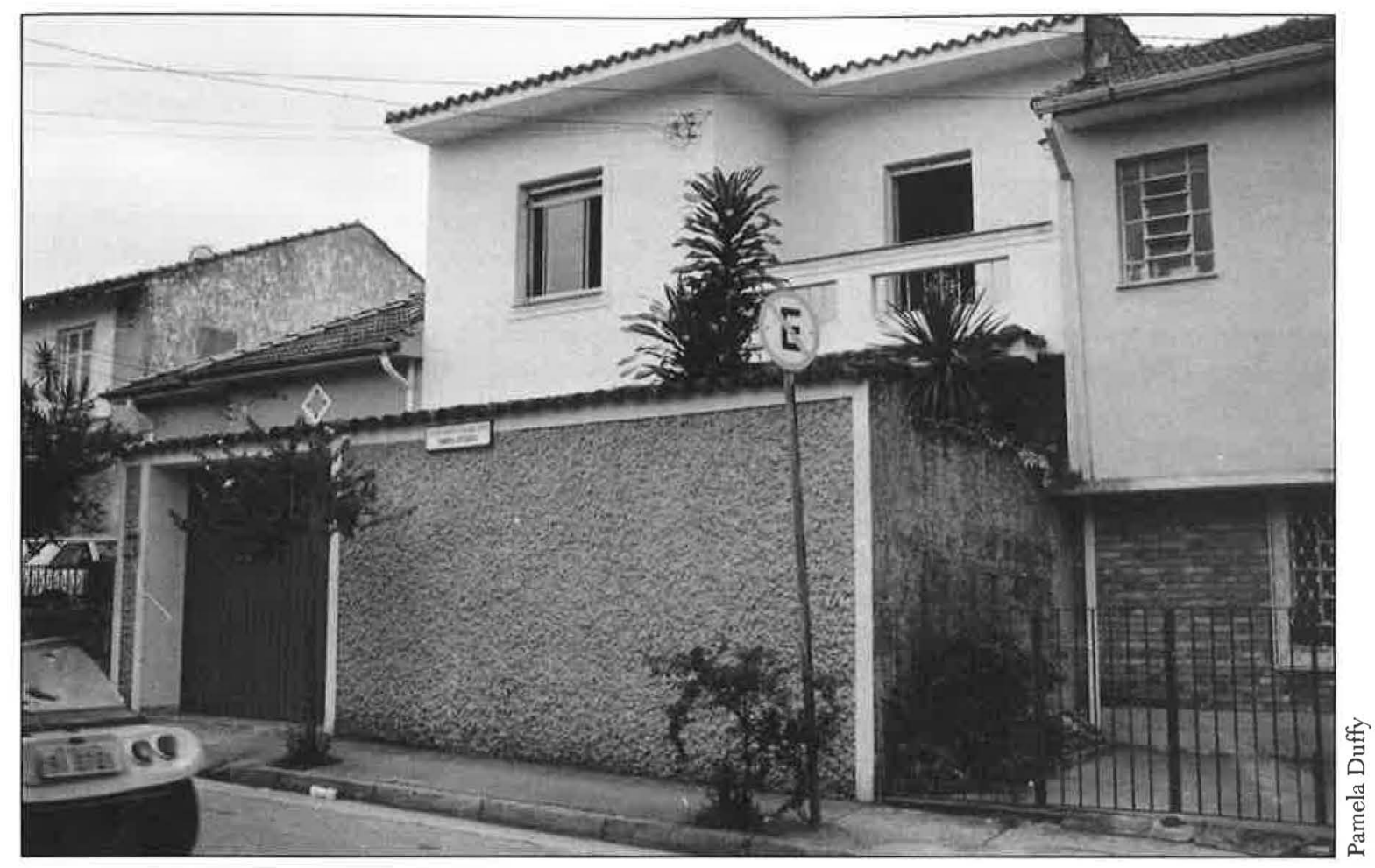

The third training option is a more individualized clinical rotation at the Coletivo. This is aimed primarily at clinicians who are also in a teaching or policy position in the public sector: Lasting three months, this course often focuses on how to provide diaphragms, as such training is not available elsewhere in Brazil. Close to 50 providers from across Latin America have attended the clinical practicum at the Coletivo. While it has not been able to systematically evaluate the impact of these training programs on the participants' professional lives, the Coletivo is encouraged by the number of "graduates" who refer their colleagues and friends to the course.

\section{Advocacy}

Brazil began its return to democracy in the late 1980s, after decades of military dictatorship. Many of the same activists who earlier fought to re-establish democracy in Brazil are today working to make that democracy meaningful, largely through the work of nongovernmental organizations. The feminist movement has been instrumental in this process of democratic construction, and its commitment to developing a civil society with popular participation and an emphasis on the values and responsibility of citizenship remain central to its work.

Indeed, while achieving reproductive freedom has become a primary concern of women's organizations around the world, Brazilian feminists were probably the first to define reproductive rights explicitly as an element of citizenship. Indeed, one of the leading voices promoting reproductive rights on the agenda of the international women's movement, as well as in Brazil, has been a successful little clinic and training program in São Paulo: el Coletivo Feminista Sexualidade e Saúde.

Among the first public advocacy projects the Coletivo helped launch was a series of dialogues (encontros) between feminists, biomedical researchers, church representatives and public health leaders on issues affecting women's reproductive health in Brazil. These biannual dialogues have focused on issues such as maternal mortality, abortion, ethics in research, and the implementation of the federal government's proposed women's health program.

Anibal Faundes, a leading family planning physician who also conducted NORPLANT ${ }^{\varpi}$ trials in Brazil, participated in these dialogues. He recalls, "the dialogue between women's health advocates and physicians is not an easy one. 
There is incomplete and often incorrect information on both sides and verbal passion within either group does not always stimulate understanding. Each dialogue experience, however, is better than the earlier one, as we all learn to listen and to accept new ideas, new perspectives, and to understand that in spite of errors committed in the past - on both sidesmany women and physicians have a common commitment to improving women's health and well-being."

Adrienne Germain, vice president of the International Women's Health Coalition (which has funded the dialogues) explains that "the dialogues gave representatives from different sectors of the society a unique opportunity to get to know each other and to seek common ground. The experience in Brazil was also important for women in countries such as Nigeria, where similar dialogues are now beginning." The Coletivo also belongs to a consortium of feminist health organizations in São Paulo that jointly produce and disseminate a magazine, Enfoque Feminista (Feminist Focus), to advocates and providers across the country.

The Coletivo's message about rethinking how we provide family planning and women's health care is also being heard by a broad range of policymakers. Maria José recently completed four years as the director of the Women's Health Program for the municipality of São Paulo. Coletivo member Simone Diniz was similarly named to a senior governmental position concerned with women's affairs. A cofounder of the Coletivo, Magaly Marques, was invited to work for International Planned Parenthood Federation/Western Hemisphere Region (IPPF) in New York, where she coordinates projects concerned with quality of care and the status of women. Coletivo members have also served as advisors to the World Health Organization's Special Programme in Human Reproduction, the Population Council and other USAID-funded agencies.

Although the Coletivo's unique way of doing business has won it admirers within the population field, many skeptics have questioned its arguments. For example, when the Coletivo staff argued at conferences that lowincome women could successfully use the diaphragm, many family planning and population professionals wanted to know: What are the pregnancy rates among these users? What are their continuation rates?

As Maria José explains, "These were

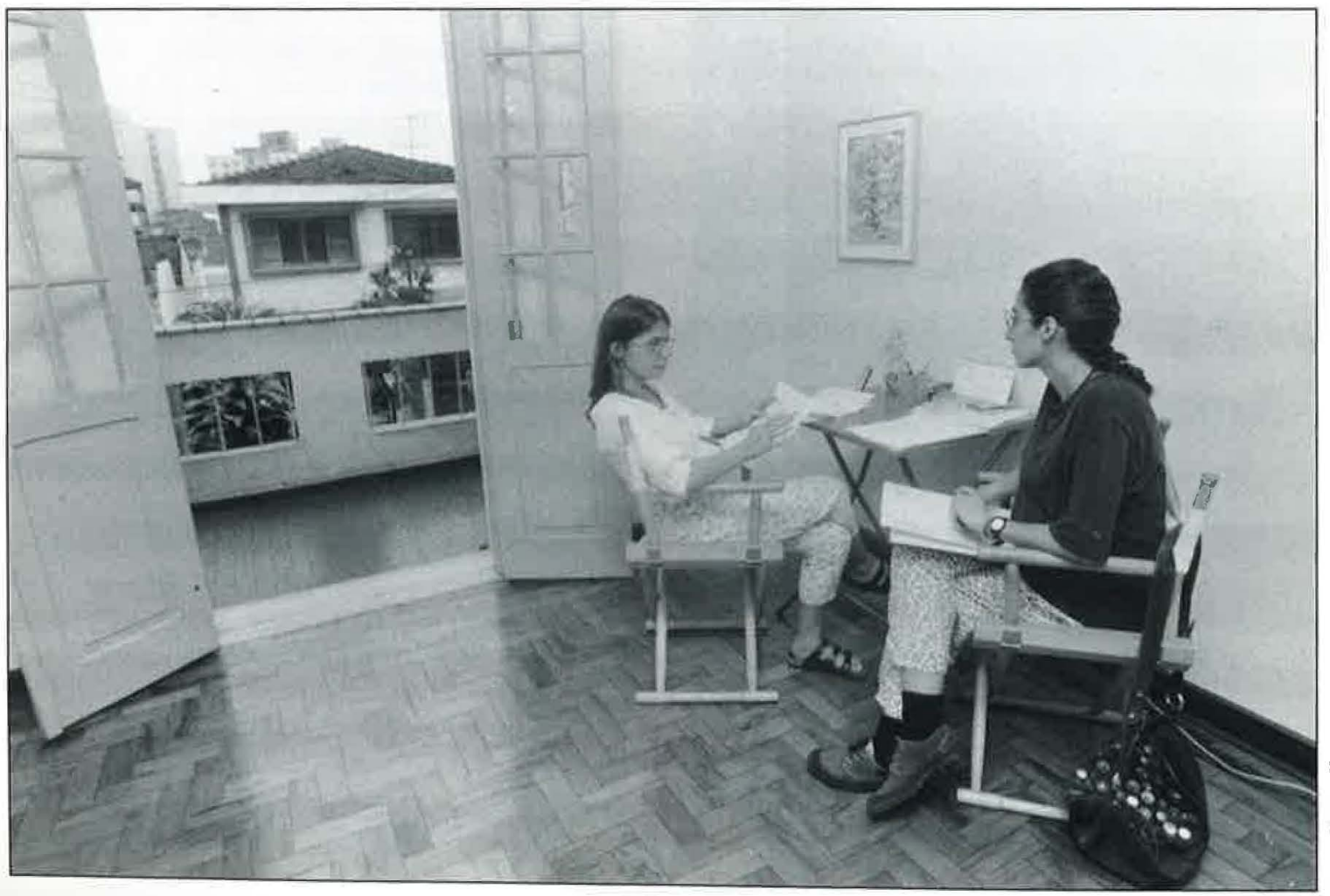


important questions, and we didn't have the answers. We began to realize that by documenting the experience of diaphragm users, we could not only demonstrate the acceptability and effectiveness of the diaphragm to policymakers, but we could also generate information about how to improve our own services. So our concerns about both policy issues and quality care eventually led us into research."

\section{The Research Program}

Although the Coletivo had carried out an informal ethnographic research study documenting clandestine abortion practice, the diaphragm study was its first formal investigation. In this effort they collaborated with two other diaphragm providers-a large university-based clinic and a private physician-to analyze outcomes of diaphragm use. The Population Council provided technical assistance.

The results surprised everyone, including the Coletivo. The first finding was that use failure rates were quite low in all three centers: a stumning 6 percent. The oral contraceptivethe most popular method in Brazil — is thought to have considerably higher use failure rates. The second finding was that 72 percent of new users were still using the method after one year. Another lesson was that low-income women proved to be just as capable as any other group in using this method. But the most startling finding had to do with a variation in protocols and outcomes among the centers. At one of the centers (not the Coletivo), the provider gave women unusual instructions for using the diaphragm: he told them to use the diaphragm without spermicidal jelly, but to leave it in the vagina at all times, removing it only to wash it and reinsert it once a day. The effectiveness and continuation rates at this center were the highest of the three sites.

The Coletivo staff is pondering these results in its unique way. Maria José comments, "We see the results as tentative, but we are intrigued. After we discussed the findings among ourselves, we shared them at special meetings with other providers and feminist advocates. Then we called meetings with our clients, both because we believe in sharing the results of research with the human subjects and also to learn what they think about these results.

"The women were very enthusiastic about the possibility that they could use the diaphragm differently. One big problem with the diaphragm is the difficulty of planning sex an hour in advance or stopping in the middle of sex to put in the diaphragm. The other problem women face is that the jelly is expensive, smells bad and is messy. If it turns out that women can really wear the diaphragm all the time and skip the jelly, this method will become an important option not only in Brazil but also across Latin America. What does it mean when we are investing millions of dollars to develop a contraceptive vaccine while we still don't know if the diaphragm needs jelly?"

Others agree that is an important question. USAID, the Population Council and the Coletivo are currently involved in discussions regarding a more carefully controlled clinical trial to examine the relative use-effectiveness and continuation rates for the diaphragm with and without jelly. In the meantime, the encouraging results even with jelly have reminded population agencies that the diaphragm is an important option not currently available in Brazil and other countries as well. Early this year; the World Health Organization's Special Programme in Human Reproduction convened an interagency working group on barlier methods involving various international population agencies. This group has made the introduction of the diaphragm into selected countries its first priority.

The idea for another research project came out of the process of preparing this article. The advisory committee of $Q / C / Q$ began to question whether the Coletivo's long-term costs per client were really as high as we had all assumed. We wanted to know how much upfront investments in quality (education, counseling, and providing real choice) can reduce the long-term costs of revisits, discontinuation, and unwanted pregnancy among dissatisfied and confused clients. The low-income status of most Coletivo clients made this question even more relevant. In collaboration with staff of the Coletivo, $Q / C / Q$ sponsored a research study to examine this question from various perspectives. 
The study had three components and the findings from all three are compelling.

\section{Cost Per Client Analysis}

At the Coletivo, the average annual cost of providing a client with comprehensive reproductive health care, including contraception is about $\mathbf{\$ 4 0}$ (from $\$ 33.49$ for pill users to $\$ 42.30$ for diaphragm users). Half of this cost is for basic family planning services and supplies. The cost for extended counseling (on topics such as sexuality and nutrition) and for reproductive tract infection screening and treatment accounts for another $\$ 10$. And the final $\$ 10$ is the cost of a Pap Smear.

Although to most programs in Brazil ten dollars seems too exorbitant to invest in basic screening, instituting universal Pap Smears was precisely the priority recommendation made by the World Bank review of women's reproductive health in Brazil. The Bank found that an investment in reducing cervical cancer was probably the most effective way to save both money and lives.

Indeed, an unapologetic up-front investment is characteristic of the Coletivo. Because the initial counseling and exam are so thorough, most new clients only get contraception at their second visit, generally one week after the first. Use of the diaphragm requires an additional follow-up check one week after the fitting (although not all women return for this third visit). So 88 percent of the total annual cost per client ( $\$ 37.22$ per diaphragm user) is invested in these early visits.

Although a few women return for contraceptive checks, changes of method or pregnancy tests, the majority of revisits after this point appear unrelated to contraceptive use. Of the remaining five dollars spent over the rest of the year, about three dollars goes toward treatment of other gynecological complaints, the most common being reproductive tract infections/STDs. Contraceptive follow-up actually costs the Coletivo only about two dollars for the remainder of the year. Thus, their intensive investment in cultivating autonomous, educated contraceptive users seems to pay off: women are coming back to the Coletivo (with infections, breast lumps, and other health prob- lems), but they generally do not have problems with their contraceptive.

\section{Cost of Effective Diaphragm Use}

With our second set of questions we sought to analyze more specifically the costs to achieve particular outcomes, specifically the realization of a diaphragm user's reproductive intentions. ${ }^{1}$ One goal of a contraceptive user is to avoid pregnancy. We adjusted the $\$ 42.30$ annual care cost to reflect diaphragm failure rate, i.e., to calculate the average annual cost per non-pregnant client.? This figure is $\$ 45.07$.

Another goal of a contraceptive user is to find a method with which she is satisfied. When we also included method continuation in the calculation, the annual cost to serve a non-pregnant woman continuing with her method after one year rose to $\$ 60.99 .^{3}$ It is important to recall that these calculations also assume that improved reproductive health is part of a client's reproductive intent.

If we were to base our calculations on the $\$ 20$ it costs for contraceptive services alone (i.e., exclude the cost of the added reproductive health care), the cost per non-pregnant client would be only $\$ 21.31$ and the cost per nonpregnant, continuing user would be $\$ 28.84$. Certainly this figure is lower than the one-year cost of providing NORPLANT ${ }^{\oplus}$, which costs $\$ 23$ for the implants alone plus considerable physician time (and which also rises further when one adjusts for discontinuation rates).

While the last set of figures may provide better comparisons to standard family planning services, they also assume that diaphragm effectiveness and continuation rates would be the same without the Coletivo's comprehensive reproductive health care package. Coletivo members doubt this would be the case and they have no interest in finding out: they believe the

'See Bruce and Jain's Implications of Reproductive Health for Objectives and Efficacy of Family Planning Programs (New York: The Population Conncil, 1993), a useful discussion of reproductive intent as a valuable contraceptive outcome measure.

${ }^{2}$ This is calculated using the total cost of serving 100 women for a year divided by the number of those women who are not pregnant at the end of the year.

${ }^{3}$ This is a similar calculation with the denominator comprised of those women who are both non-pregnant and continuing users. 


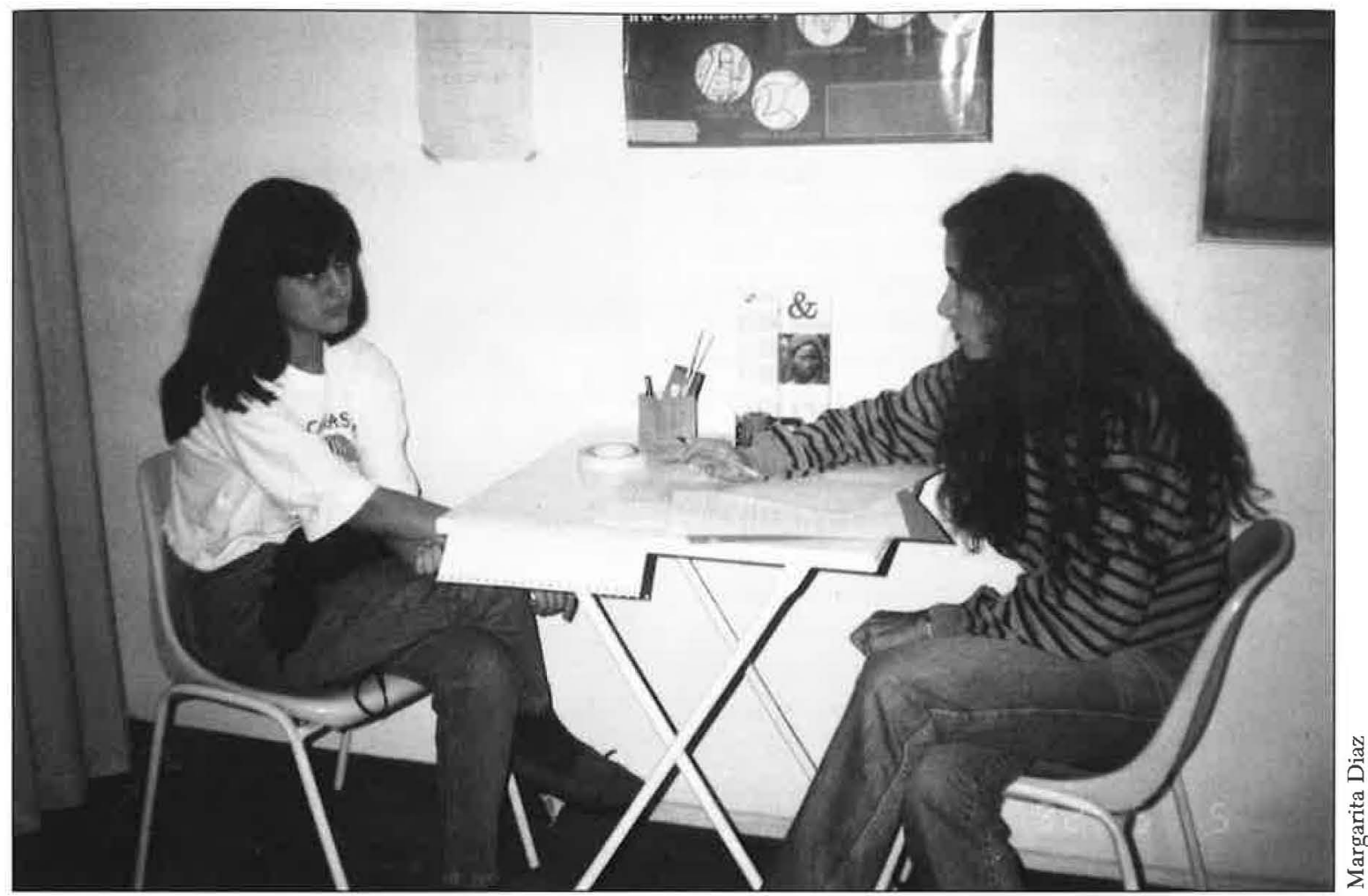

reproductive health package is vital in its own right and should not be viewed solely as a means to enhance contraceptive use.

At the Coletivo another element of clients' "reproductive intent" is for women to feel more knowledgeable about and comfortable with their reproductive organs. Unfortunately, prospective contraceptive trials have never included self-awareness and comfort levels as an outcome variable. While there is strong anecdotal data indicating the importance of such awareness and comfort to clients, we have no quantitative data which would allow us to measure the rate with which this outcome is achieved.

\section{The Costs of Achieving a Desired Outcome: Oral Contraceptive Use}

In Brazil the oral contraceptive is freely available over the counter. The retail cost for 12 pill-packs of the brand used by the Coletivo is about $\$ 24$. Obviously, this is considerably less than the $\$ 33.49$ it costs for a year of comprehensive reproductive health care and pills at the Coletivo. But what kind of results are actually being achieved through over-the-counter provision of the pill?

We wanted to know what it cost the Coletivo for each pill user who was both clini- cally appropriate and satisfied with the information she had received along with the pill. ${ }^{4}$ An audit of client charts found that 100 percent of pill users at the Coletivo had been screened for basic contraindications, and a survey of their pill users found that 72.5 percent of clients felt satisfactorily informed about the pill. Adjusting for these figures, the Coletivo's cost of serving a satisfactorily informed, clinically appropriate pill user increases to $\$ 46.19 .{ }^{5}$

We then carried out a parallel analysis for women who have always gotten the pill from a pharmacy. Earlier research by Hardy et al demonstrated that one-fourth of women getting oral contraceptives from pharmacies had absolute contraindications to pill use. ${ }^{6} \mathrm{Our}$ sur-

\footnotetext{
' Well-informed use is part of basic informed consent; client satisfaction with the information process was selected as the most practical indicator for this study. Other indicators of well-informed use also appear in the literature.

${ }^{5}$ Again, we arrive at the adjusted figure by calculating the total cost of providing 100 pill users with comprehensive reproductive health care plus contraception for a year, divided by the number of those women who were satisfactorily informed and clinically appropriate users, i.e., $\$ 33.49 \times 100$ 우/72.5

${ }^{6}$ Hardy E.E., et al, "Contraceptive pill: adequacy of use anong women in unions. [Adequacao do uso de pilula anticoncepcional entre mulheres unidas]," Revista de Saude Publica. v. 25 n. 2 pp. 96-102, 1991.
} 
vey of 141 women who regularly get their pills from the pharmacy also found that only 16 percent felt they had been satisfactorily informed about the method. Adjusting for these outcomes, the cost of achieving a satisfactorily informed, minimally clinically indicated pill user from the over-the-counter system rises astronomically from $\$ 24$ to $\$ 200 .^{\bar{\gamma}}$ From any policy perspective that respects clinical screening and informed consent, the Coletivo's thorough approach now begins to look prudent.

The Coletivo developed its program based on the belief that there are social payoffs to a society which help women become more autonomous in their sexual lives. This fairly extensive cost-analysis, in combination with the World Bank review, suggests there are compelling financial payoffs as well." Many donors are now rethinking the narrow outcome indicators used in the past (such as couple years of protection- $\mathrm{CYP}$ - and numbers of new acceptors) in favor of more meaningful indicators of reproductive health and satisfactory fertility regulation.

\section{Coletivo Members Speak about the Ups and Downs}

Have there been difficulties and doubts along the way? Of course.

Ten years ago Rosa Dalva Faustinone Bonciani was among the Coletivo's founders. Today, at 42 , she reflects back on her individual concerns and those of the group. "At that time, I didn't know this would be a life project. I come from a very poor family in the country and was studying to become a pharmacist. I had stopped my studies to care for my two children. Then I met Maria José and decided to help start the Coletivo. I did finally finish my studies but I never really worked as a pharmacist. So I don't have a profession in the formal sense to fall back on.

"The work has its difficulties. This is a laboratory. We learn, we invent a new way of working. This is not easy, trying to overcome old, crystallized ways of being--personally and professionally."

\footnotetext{
${ }^{7}$ In this case, the calculation is $\$ 24 \times 100$ \%/16x.75.

${ }^{8}$ The investigators are currently preparing a more detailed discussion of this cost-effectiveness study for separate publication.
}

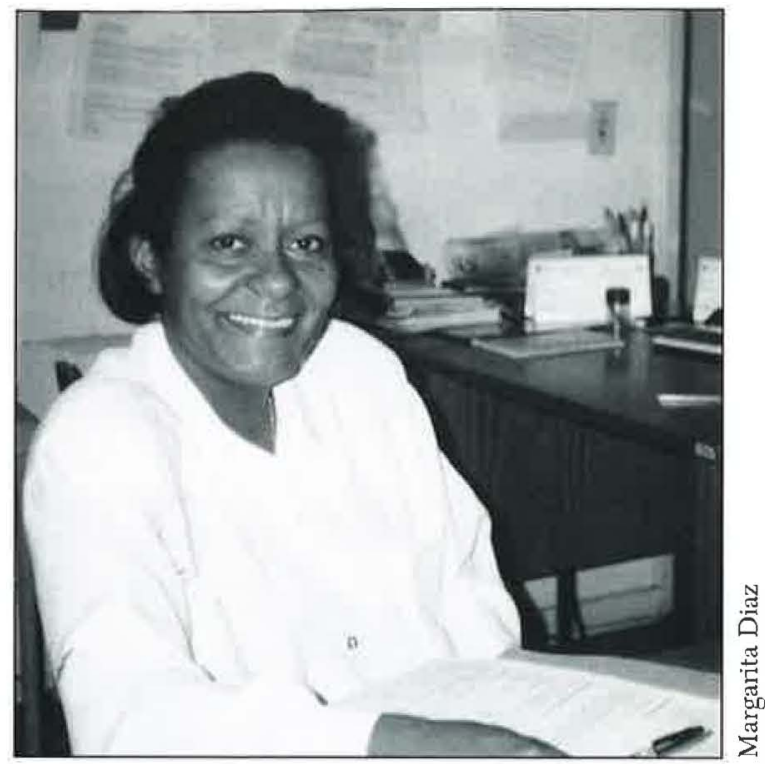

Despite the emphasis on equality, "status" still comes into play. Often it is the physicians, Maria José and Simone, who are invited to participate in international meetings. This places a particular strain on the Coletivo, because it is difficult to recruit other physicians to join an unhierarchical, as well as low-paying organization.

Over the years, several members have taken leaves of absence to pursue other interests and then returned. Several have restored their original enthusiasm and commitment through opportunities to travel and meet with feminist health advocates and policymakers in the international arena. And while new members have joined, a few old friends have parted not to return.

But the greatest ongoing problem the Coletivo has faced is the same issue most programs face: finances. Rosa explains, "The hardest part has been the lack of professional security. We constantly depend on outside finances. As a result of our limited finances, there is only [enough] funding for me to work part-time, and I have to work in another job to support my family."

Because it is outside the circle of programs supported by mainstream population donors such as USAID, the United Nations Population Fund or IPPF, the Coletivo has relied on support from the International Women's Health Coalition, the MacArthur Foundation, European foundations, and other 
private donors. Client fees continue to provide a significant contribution toward covering costs, but meeting the remainder of expenses on a steady basis has always been-and may always be-an ongoing worry for the Coletivo.

Despite the problems, Coletivo members insist that their work is a tremendous source of personal pride. Rosa explains, "Sure, it's a constant challenge. But every time we take a step forward, we feel 'This is worth it.' And people admire me for working here, even when they don't really understand what the Coletivo is. They feel moved. My oldest brother finds it very interesting that I came from a rural village, have six sisters, and ended up here! The answer? I don't know, something I found in myself gave me the impulse to rebel against the submission and domination-including economic domination - that is machismo, which is so strong in the countryside."

Thirty-one-year-old Celia Cipriano joined the Coletivo six years ago by answering a classified advertisement for a bookkeeper. She smiles and recalls, "I had never heard of feminist collectives. It scared me. I was a bit lost the first six months, as I learned about health and women's issues. But I think I make an important contribution here. And I've grown so much personally. I get to attend conferences. I particularly try to go to conferences about abortion and ones about using humor at work. And I refer my friends here. People love the workshops, like the one called 'Our Dreams.'

"My mother, Sofia Elias Cipriano, worked here for a while too-still does sometimes, cooking and maintaining the building. My mom had a sixth grade education. Here she came to know another way of life for herself, among people who were very open and friendly."

We asked Celia about the disadvantages of working at the Coletivo. She told us she "still hasn't found them."

Simone Grilo Diniz is a physician and a long-time feminist. In addition to providing clinical support at the Coletivo, Simone is engaged in research and training. She explains, "Before the Coletivo, I had my work as a feminist activist on one side and my work as a physician on the other. The Coletivo allowed me to synthesize these sides of myself. And it has allowed me to see that the problems we experience as women are not just our own, isolated problems. This has had a good impact on my self-esteem. In this sense, having an active political commitment becomes very calming!"

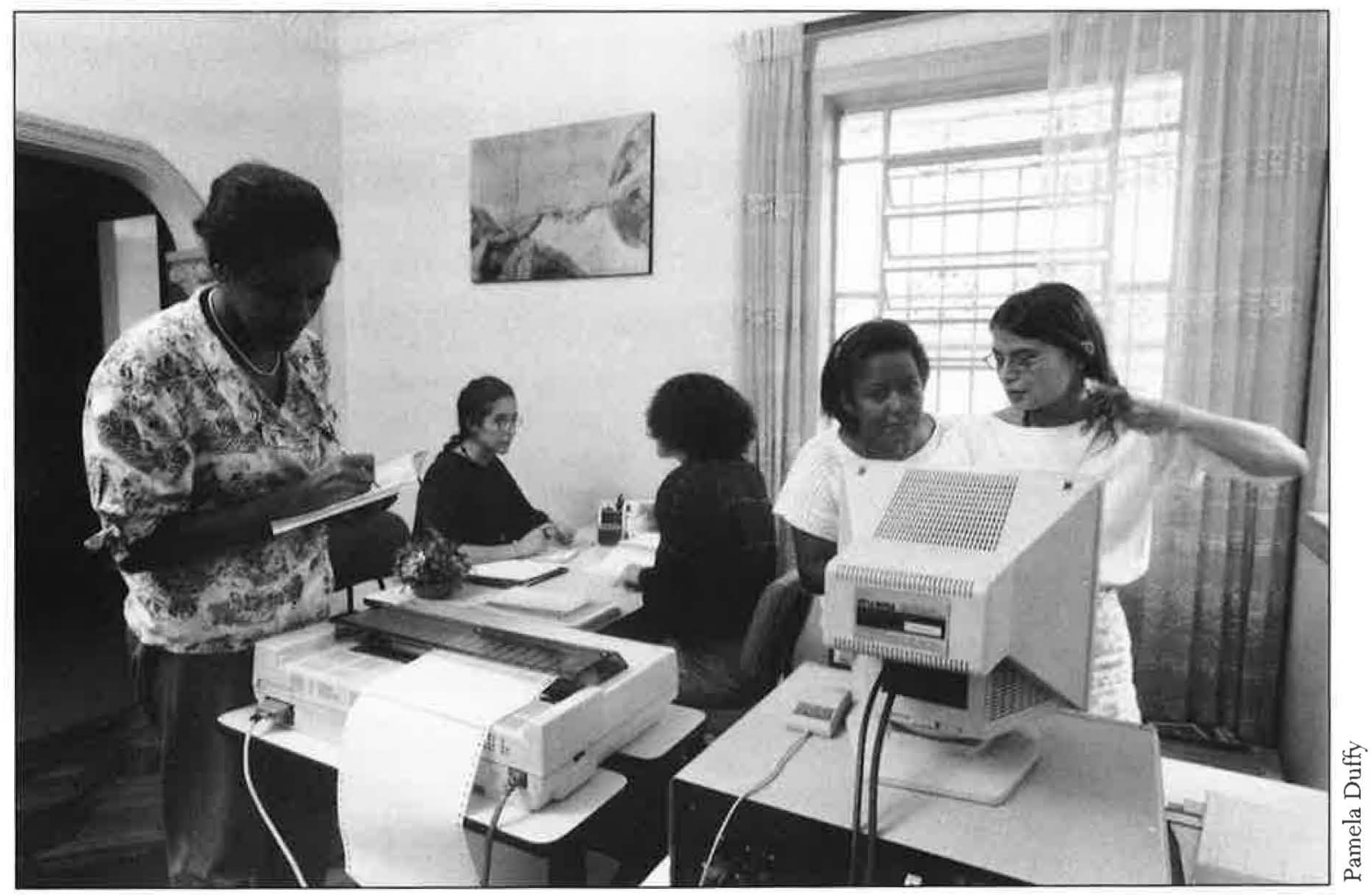


Maria Jucinete De Souza enrolled in a health and sexuality group that the Coletivo organized in her low-income neighborhood in the mid-1980s. Today she performs pelvic exams as a Coletivo staff member. In reflecting on the path her life has taken, she muses, "I got married, came here from Bahia (a poor state in the northeast of Brazil), and then I had my children. I was a housewife and also a domestic worker: After attending the sexuality workshop, I could see that the life I was leading was not the one I wanted.

"I began to participate in the meetings of the women's movement, relaxation groups and in neighborhood organizing. In this way I came to know Maria José, who was organizing a training course for women's health care. I was interested and decided to participate. I realized that my childhood hope of becoming a teacher was still there, but with a different angle: to be an educator in the area of women's health. Even though I hadn't gone to high school, the training and help I got from the other women at the Coletivo enabled me to become a clinician, which I still am today.

"The personal changes have been so big compared to the tasks I was doing as a housewife. Now I have the opportunity to improve myself financially and also to grow as an individual capable of achievements. Every time clients come back to the clinic or tell their friends about us, I feel these achievements are acknowledged."

\section{Next Steps}

By the early 1990s, rent of the Coletivo's clinic had risen to 20 percent of its total budget. So in 1993, with funds raised both in the U.S. and Brazil, Coletivo members realized one of their long-term dreams: they bought their own building. Located across the street from the former location, the new Coletivo is situated in a large, airy and beautiful former residence. Since moving in, the Coletivo's operating costs have declined significantly, offering the group some marginal fiscal security. But beyond this, the staff members sense a new pride and confidence in the organization's stability. The Coletivo staff is currently looking forward to carrying out the next stage of diaphragm research, collaborating on the cost-benefit analysis, adding a few new members (particu- larly another physician) and exploring the issue of male involvement.

In the meantime, the phone rings and there is another woman with an unwanted pregnancy whom they wish they could help. A letter arrives requesting the Coletivo to host three visitors from the Philippines. A fax announces a meeting about a proposed sterilization law. And the door opens and a woman enters. The Coletivo is reminded once again why it carries on. Such are the blessings and the burdens of what Rosa calls "a work of passion."

\section{Lessons Learned}

The Coletivo runs a clinic, a training institute and a public education program. It provides leadership to the Brazilian government and women's health movement and is active in research and international policy affairs. Such accomplishments would be impressive for any program. Remember, reader, that this is a group of just 11 women.

Based on their personal experiences, the Coletivo members never strayed from their belief that by learning about their bodies and actively participating in the design of their own health care they, as women, could not only improve their health but also strengthen their identities as women, as sexual beings and as citizens. They set out to enable individual clients to know their own bodies, make their own choices, recognize their own rights. They have "given voice" to thousands of women. Twelve years later, the Coletivo has found its own voice, taking what it has learned by providing services and speaking to the world.

What can we learn from the story of the Coletivo Feminista?

1. By knowing what it stands for, even a small program can have an enormous impact in shaping ideas and options for women's health care. The Coletivo has never deviated from its original objectives and its membership has remained fairly stable. Yet it has managed to continually evolve, remaining open and flexible to new ideas and different perspectives. Rather than resting on its laurels, the Coletivo has constantly sought new allies and new avenues in an effort to reach closer to its ambitious goals.

2. Women place great value on services that meet their health needs as they 


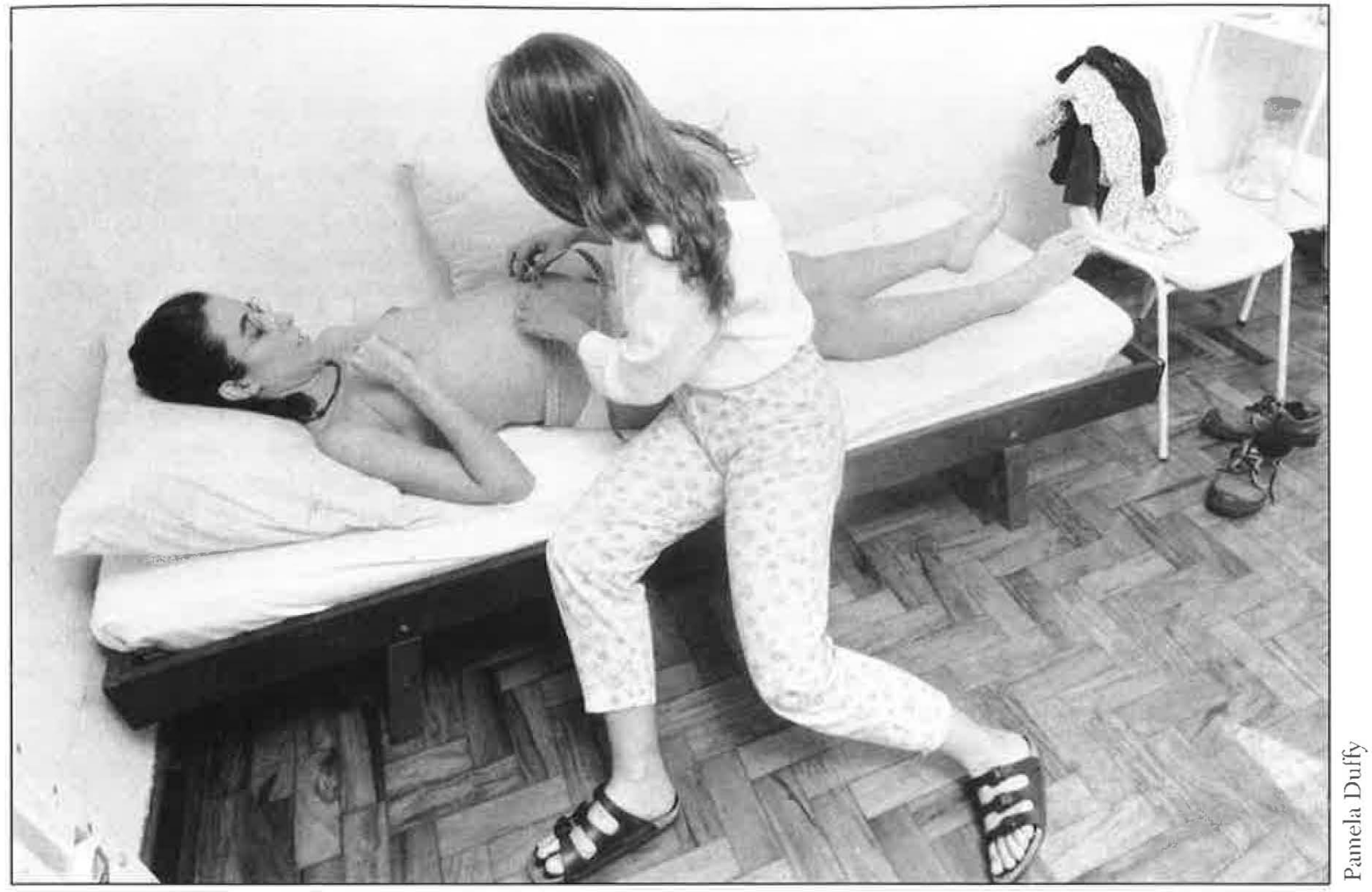

perceive them. Although finances make it impossible for most services to provide clients with the time and attention they receive at the Coletivo, it is important for us to know how much women value such care. If we understand women's priorities, we are better equipped to think creatively about how to respond to them and to argue more effectively that their needs be considered by policymakers. Because if we lose sight of what women really want, we can easily get lost despite our efforts to improve the quality of care.

3. Those of us involved with family planning research, policymaking and program implementation can gain new ideas and establish useful working relationships from communication and collaboration with feminist health advocates.

4. Never underestimate the power of the human spirit-or your own imagination!

\section{To Our Readers}

Initially, we at Quality/Calidad/Qualité thought this essay might have to be written either for those women around the world thinking about starting alternative programs, or for established family planning professionals wanting to understand more about the international feminist health movement. Ultimately, we have tried to keep both audiences in mind. We would love to hear from you about this issue. Tell us about your yourself and your responses to reading about the Coletivo. 


\section{Resumo em português}

No passado, programas de planejamento familiar eram desenhados primordialmente com o objetivo de reduzir o excesso do crescimento populacional, fazendo das mulheres objetos de políticas medicalizadas e de programas desenhados com o objetivo de regular sua fertilidade. Após a recente Conferência Internacional de População e Desenvolvimento (Cairo 1994), a necessidade de uma visão mais ampla em relaçâo à saúde reprodutiva tem sido fortemente apoiada; porém, existem ainda várias questōes relacionadas à implementação destes objetivos. Esta edição do $\mathrm{Q} / \mathrm{O} / \mathrm{Q}$ documenta a experiência de um grupo de mulheres brasileiras que se juntaram em busca de alternativas ao tratamento medicalizado da saúde feminina e acabaram abrindo sua própria clínica.

As membras do Coletivo passaram anos fazendo pesquisa, conversando com mulheres a respeito de sua saúde e buscando o treinamento necessário para oferecê-las um tratamento amplo de saúde reprodutiva. Para a grande maioria das mulheres brasileiras, uma visita a um ginecologista (que na maioria dos casos é um homem) é uma experiência desagradível; baseado nisto, o Coletivo decidiu treinar mulheres leigas para fornecer exames ginecológicos básicos, com a presença de uma médica na clínica. Este conceito de tratamento reconhece que as necessidades de saúde das mulheres estão intrinsecamente relacionadas com sua sexualidade, seu papel na sociedade, suas atividades econômicas e seu bem-estar emocional. Como resultado, as clientes saem da clínica com um maior reconhecimento do seu corpo e de sua sexualidade. Além do mais, o Coletivo enfatiza a prevenção e o uso de remédios naturais para diminuir a dependência da tecnologia médica e dos remédios alopáticos.

Atualmente o Coletivo tem seu próprio prédio e possui 11 membras que atendem uma média de 250 mulheres anualmente. As atividades do Coletivo constam das seguintes: serviços clínicos, programas educacionais, treinamento, advocacia e pesquisa. Os preços dos serviços são baseados no poder aquisitivo das clientes $\mathrm{e}$, considerando-se os problemas econômicos do Brasil, os lucros com estes servigos representam apenas 17 por cento do orçamento total da organização. Entretanto, como o objetivo principal do Coletivo é o de criar um modelo de assistência de saúde e não a auto-suficiência, a organização continua a depender da ajuda de doadores.

No Brasil, 85 por cento das mulheres usam a pílula anticoncepcional e a esterelização como métodos contraceptivos; outros métodos contraceptivos são praticamente inacessíveis. Este fato foi inaceitável para uma organização que se preocupa em poder oferecer opções às mulheres. Porém, oferecer outros métodos contraceptivos no Brasil também não é fácil. Sendo assim, o Coletivo teve que procurar um dos poucos lugares no país onde se oferecia treinamento para inserção do DIU.

O Coletivo também se sentiu muito motivado em oferecer o diafragma às suas clientes. Isto porque a organização não estava somente preocupada com o grande número de mulheres tomando pílulas com contra-indicação, mas também porque queria oferecer às mulheres uma opção que lhes permitisse começar ou parar de usar um método quando quizessem, e que este método pudesse ao mesmo tempo oferecer alguma proteção (quando usado em conjunto com o espermicida) contra infecções. $\mathrm{O}$ argumento mais comum existente contra o diafragma é o de que toma muito tempo para ensinar o seu uso correto para as mulheres. Porém, tempo não representa uma questão para o Coletivo: a primeira consulta de uma cliente dura aproximadamente uma hora e visitas posteriores duram aproximadamente 30 minutos. Enquanto alguns programas de planejamento familiar podem considerar isto impraticável, o pessoal do Coletivo crê que este tempo dedicado às consultas é necessário para que as mulheres possam discutir suas preocupações, aprender sobre seus corpos, se tornarem cientes dos serviços ofereciclos pela clínica e estabelecer um relacionamento de confiança com a profissional de saúde.

E investir no tempo compensa, pois atualmente quase 40 por cento das clientes de contraceptivos que visitam o Coletivo vão à procura do diafragma, e o Coletivo recebe também referências vindas de outras clínicas. Respondendo ao interesse crescente no método, assim como em sua filosofia centrada no cliente, o Coletivo atualmente oferece cursos para profissionais de saúde provindos de outros estados do Brasil e de outros países latinoamericanos.

O Coletivo também desenvolve pesquisas que documentam o sucesso de sua filosofia. Recentemente, a organização foi escolhida dentre a outros três lugares para participar de um estudo sobre o uso do diafragma, que resultou num índice de falência de somente 6 por cento, isto é, um índice bem menor que o atribuído à pílula no Brasil. Como parte do processo de produção desta publicação, a organização também participou de um estudo de pesquisa simples que demonstrou que o investimento inicial do Coletivo no tempo é lucrativo, quando a medida deste resultado é o sucesso de um método e a satisfação da cliente.

O Coletivo Feminista Sexualidade e Saúde continua a explorar novas formas de oferecer seus serviços de maneira que as mulheres participem de sua própria saúde reprodutiva. Através de seu trabalho, elas nos mostram que isto é possível, contanto que estejamos prontas para enfrentar desafios. 


\section{Resumen en Español}

En el pasado, los programas de planificación familiar eran diseñados con el propósito exclusivo de reducir el crecimiento excesivo de la población. Con este fin, muchos de estos programas convertían a la mujer en un objeto de políticas médicas que buscaban controlar su fertilidad. Desde que concluyó la Conferencia Internacional Sobre Población y Desarrollo (El Cairo, 1994), muchos sectores han reconocido que la salud reproductive requiere una perspectiva más amplia, aunque muchos todavía preguntan cómo dicha apertura se puede llevar a cabo. Esta edición de Q/C/Q relata la experiencia de un grupo de mujeres en Brasil que se formó como alternativa a la tradición medicalizada en la salud femenina y terminó por formar su propia clínica.

Las miembras del Coletivo dedicaron varios años a la investigación, entrevistando a mujeres sobre temas de salud y consiguiendo la capacitación necesaria para ofrecer un servicio completo de salud reproductiva. Para la mayoría de las mujeres en Brasil, las visitas al ginecólogo [que casi siempre es varón] suelen ser experiencias desagradables. Por lo tanto las mujeres del Coletivo decidieron entrenar a voluntarias para que pudieran realizar exámenes ginecológicos básicos, bajo la supervisión de ginecólogas profesionales. El enfoque del Coletivo reconoce que las necesidades médicas de la mujer están íntimamente ligadas a su sexualidad, su papel en la sociedad, su actividad económica y su bienestar sicológico. Las mujeres que pasan por la clínica del Coletivo salen con una mejor comprensión de sus cuerpos y de su sexualidad; la clínica hace incapié en la prevención y el uso de remedios naturales para reducir la dependencia en tecnología y drogas.

En la actualidad el Coletivo cuenta con un edificio propio y un equipo permanente de 11 miembras que sirven a unas 2,500 mujeres por año. Las actividades se dividen en cinco ámbitos: servicios clínicos, programas educativos, capacitación, asesoramiento legal e investigación. Los servicios se cobran en base a los ingresos del cliente; dados los problemas económicos de Brasil, estos ingresos sólo representen el 17\% del presupuesto total del Coletivo. El propósito del coletivo siempre ha sido crear un modelo de la calidad en la atención, no uno de autosuficiencia económica, por lo cual la clínica sigue dependiendo del apoyo de agencias donantes.

Los anticonceptivos orales y la esterilización representan el $85 \%$ del uso total de anticoncepción en Brasil; los otros métodos casi no existen. Para una clínica que buscaba proveer verdaderas opciones anticonceptivas, esta era una situación inadmisible.
No obstante, resulta muy clifícil ofrecer otros métodos en Brasil; las miembras tuvieron que buscar los pocos sitios en el país donde se ofrece capacitación en la inserción de DIUs.

Las miembras del Coletivo también querían poder ofrecer el diafragma. No sólo les preocupaba el elevado número de mujeres que dependen de anticonceptivos orales a pesar de presentar contraindicaciones para el uso de la píldora, sino que querían poder ofrecer una opción anticonceptiva que fuera fácil del iniciar y dejar a corto plazo, a la vez que ofreciera un nivel de protección contra infecciones (siempre y cuando se lo utiliza con espermicidas). El argumento típico en contra del diafragna es que para asegurar el uso correcto se requiere demasiado tiempo para la orientación inicial de la usuaria. Pero al Coletivo le sobra el tiempo. Las visitas iniciales duran en promedio una hora, y las siguientes típicamente alacanzan los 30 minutos. Aunque muchos programas de planificación familiar no podrían aceptar este tipo de horario, el personal del Coletivo cree esta es la única manera de poder explorar todas las inquietudes de las ususarias, educarlas sobre sus propios cuerpos, familiarizarlas con los servicios disponibles en la clínica y establecer una relación de confianza.

Esta inversión en tiempo ha clado buenos resultados. Hoy en día casi el $40 \%$ de las mujeres que buscan un método anticonceptivo en el Coletivo piden el diafragma, y muchas de estas vienen referidas de otras clínicas. Como respuesta al creciente interés en este método y en el enfoque particular de la clínica, el Coletivo ha empezado a ofrecer cursos de capacitación para profesionales de salud que vienen de otras partes del Brasil y América Latina.

El Coletivo también realiza investigaciones con el propósito de documentar el éxito de sus prícticas. Recientemente la clínica tomó parte en un estudio sobre la utilización del diafragma (con dos otras clínicas) que encontró una taza de embarazo de sólo $6 \%$ - un nivel mucho menor al de la píldora en Brasil. Como parte de la preparación de este folleto el Coletivo también participó en varios estudios que demostraron que la inversión de tiempo hecha por la clínica resulta costoeficaz cuando se la mide en términos de la utilización exitosa de anticonceptivos y la satisfacción de las usuarias.

El Coletivo sigue creando nuevas maneras de proveer servicios e involucrar a las mujeres en el cuidado de su propia salud. A través de su trabajo, las integrantes del Coletivo nos demuestran lo que se puede lograr si estamos dispuestas a aceptar el desafío. 


\section{Résumé en Français}

Autrefois, les programmes de planification familiale avaient pour but principal de réduire la croissance excessive des populations, faisant des femmes l'objet de politiques médicalisées et de programmes destinés à réglementer leur fertilité. Suite à la récente Conférence Internationale sur la Population et le Développement (Le Caire 1994), la nécessité d'une approche plus globale concemant la santé génésique (reproductive) a été largement endorsée. Cependant, nombreux sont ceux qui se demandent comment s'y prendre. Cette édition de $\mathrm{Q} / \mathrm{C} / \mathrm{Q}$ documente l'expérience d'un groupe de femmes brésiliennes qui, unies dans la recherche d'altematives aux soins médicaux destinés aux femmes, ont fini par ouvrir leur propre clinique.

Les membres de Colectivo ont passé des années à faire des recherches, parlant aux femmes de leur santé et recevant la formation nécessaire pour offrir à celles-ci des soins compréhensifs de santé reproductive. Pour la plupart des femmes du Brésil, une visite chez le gynécologue (presque toujours de sexe masculin), est une expérience tellement désagréable que Colectivo a décidé de former des personnes qui ne sont pas du métier, à donner, avec l'appui de femme-médecins, de simples examens médicaux. Leur approche reconnait que les besoins des femmes dans ce domaine, sont directement reliés à leur sexualité, leurs rôles sociaux, leurs activités économiques et leur bien-être émotionnel. Ainsi, les clientes de Colectivo quittent la clinique avec une meilleure compréhension de leur corps et de leur sexualité. En outre, Cólectivo met l'accent sur la prévention et l'utilisation des remèdes naturels afin de réduire l'extrême dépendance sur la technologie et les drogues.

Aujourd'hui Colectito possède ses propres batiments et emploie 11 membres qui servent près de 2500 femmes chaque année. En général, les activités sont divisées en cinq sections: les services cliniques, les programmes éducationnels, la formation, les plaidoiries et la recherche. Les problèmes économiques du Brésil étant pris en considération, les honoraires des clients sont calculés selon leur pouvoir d'achat, et, représentent seulement 17 pourcent des revenus. Cependant, le but de Colectivo a toujours été de créer un modèle de qualité des soins et non un modèle d'auto-suffisance. Par conséquent, l'organisation continue à dépendre de l'assistance des bailleurs de fonds.

Au Brésil, les autres méthodes n'étant pratiquement pas disponibles, les contraceptifs oraux et la stérélisation représentent près de 85 pourcent de l'ensemble des différents contraceptifs utilisés. Ceci n'était pas acceptable pour une organisation qui a comme but de donner des options aux femmes. Mais offrir d'autres méthodes au Brésil n'étant pas facile, les membres ont du rechercher un ou deux endroits dans le pays où une formation en insertion des DIV était disponible.

Colectivo était également décidé à rendre le diaphragme disponible à ses clientes. Elle était non seulement concernée par le grand nombre de cas de contre-indications pour les femmes utilisant la pilule, mais elle voulait aussi offrir aux femmes une option leur permettant de commencer ou d'arrêter volontairement une méthode; méthode qui dans ce cas, pourrait offrir une protection contre les infections lorsqu'elle est utilisée avec un spermicide. L'argument généralement utilisé contre le diaphragme est que le temps pris pour former les femmes à sa bonne utilisation est trop long. Mais le temps n'est pas un problème pour Colectivo. Les premières visites prennent en moyenne une heure et les visites suivantes à peu près 30 minutes. Alors que de nombreux programmes de planification familiale considèrent ce lapse de temps peu efficace, le staff de Colectivo le croit indispensable pour que les clientes puissent explorer, de manière satisfaisante, toutes leurs préoccupations, apprendre à connaitre leur corps, découvrir les services qui leur sont disponibles et établir une relation de confiance avec les membres de la clinique.

Cet investissement en temps vaut la peine. Aujourd'hui près de 40 pourcent des clientes pour la contraception demande le diaphragme et Colectivo reçoit maintenant de nombreuses recommandations des autres cliniques. En réponse à l'intérêt accru pour cette méthode, ainsi que leur approche centrée sur la cliente, Colectivo offre maintenant plusieurs cours de formation pour les professionnels en soins de santé qui viennent d'autres régions du Brésil et de l'Amérique Latine.

Colectivo entreprend également des recherches pour documenter le succès de leur approche. Récemment, elle était un des trois sites choisi au Brésil pour participer à une étude sur l'utilisation du diaphragme, une méthode qui a un taux d'échec de seulement 6 pourcent - taux beaucoup plus bas que celui de la pilule. Comme partie intégrante au processus de développement de cette publication, Colectivo a également participé à de simples études de recherche qui ont démontré que son investissement initital en temps était en fait efficace au niveau coût, particulièrement quand on le mesure en terme de l'utilisation réussie d'une méthode et de la satisfaction dı client.

L'Entreprise Collective sur la Sexualité et la Santé des Femmes continue à être une pionnière dans les nouvelles manières d'offrir des services et d'amener les femmes à être plus responsable de leur santé. A travers son travail, elle nous montre ce qui est possible si nous sommes prêtes à relever le défi. 


\section{About the Authors}

Debbie Rogow is a senior consultant to international reproductive health organizations. Margarita Diaz is a practicing registered midwife who has worked in research and training in the areas of family planning and sexual health in Chile and Brazil; she currently heads the Education, Training and Communication Unit at CEMICAMP in Brazil. José Barzelatto is Director of the Reproductive Health and Population Program of the Ford Foundation which focuses on social, cultural and economic factors affecting improved reproductive health and sexuality.

\section{Quality/Calidad/Qualité Advisory Committee}

\author{
Ian Askew \\ Karen Beattie \\ George Brown \\ Judith Bruce \\ Ethel Churchill
}

Nancy Newton

John Paxman

Geeta Rao Gupta

Debbie Rogow

Jill Sheffield

$\mathrm{H} Q$

766

Diaz, Margarita.

.033

The Coletivo

no. 6

\section{POPULATION COUNCIL LIBRARY NEW YORK}

Cover Photo:

Typography:

Printing:
G,AYLORD S

Pamela Duffy

Line \& Tone Group, Inc.

Graphic Impressions

We invite your comments and your ideas for projects which might be included in future editions of Quality/Calidad/Qualité. If you would like to be included on our mailing list, please write to Ann Leonard, Quality/Calidad/Qualité, The Population Council, One Dag Hammarskjold Plaza, New York, N.Y. 10017, U.S.A. 